Journal of Current and Advance Medical Research

July 2018, Vol. 5, No. 2, pp. 42-44

http://www.banglajol.info/index.php/JCAMR

ISSN (Print) 2313-447X

ISSN (Online) 2413-323X

DOI: http://dx.doi.org/10.3329/jcamr.v5i2.37057

ORIGINAL ARTICLE

OPEN ACCESS

\title{
Histopathological Study of Malignant Neoplasm of Breast of Different Age and Sex Groups In a Tertiary Care Hospital
}

\author{
Nazmun Nahar ${ }^{1}$, Mohammed Iqbal ${ }^{2}$, Kazi Md. Shahidur Rahman ${ }^{3}$, Md. Abdullah Yusuf ${ }^{4}$, \\ Shahed Iqbal ${ }^{5}$, Shahana Hossain ${ }^{6}$
}

\begin{abstract}
${ }^{1}$ Associate Professor \& Head, Department of Pathology, Medical College for Women \& Hospital, Uttara, Dhaka, Bangladesh; ${ }^{2}$ Associate Professor, Department of Anatomy, Monno Medical College, Manikganj, Bangladesh; ${ }^{3}$ Assistant Professor, Department of Pathology, Monno Medical College, Manikgonj, Bangladesh; ${ }^{4}$ Assistant Professor, Department of Microbiology, National Institute of Neurosciences \& Hospital, Dhaka, Bangladesh; ${ }^{5}$ Associate Professor, Department of Pediatrics, Chattagram Maa-O- Shishu General Hospital, Agrabad, Chittagong, Bangladesh; ${ }^{6}$ Associate Professor \& Head, Department of Anatomy, Tairunnessa Memorial Medical College, Gazipur, Bangladesh
\end{abstract}

[Received on: 2 March 2018; Reviewed on: 12 April 2018; Accepted on: 10 May 2018; Published on: 1 July 2018]

\section{Abstract}

Background: Various types of female breast cancer associated with rapidly increasing age incidence. Objective: The purpose of the present study was to find out the frequency of different types of malignant neoplasm of breast in different age and sex. Methodology: This cross-sectional study was carried out at the Department of Pathology, Chittagong Medical College, Chittagong, Bangladesh from May 2005 to June 2006. Patients presented with breast lump of different age and sex were subjected to this study. Details gross examination was done followed by $\mathrm{H} \& \mathrm{E}$ staining for histopathological study. Result: A total number of 48 samples were selected after fulfilling the inclusion and exclusion criteria. This present study conducted in 27 specimens out of 48 breast lump. Among these benign and malignant were 21 and 27, respectively. Majority of the malignancy found in age group 41-50 years. Histopathologically Invasive ductal carcinoma was common $81.5 \%$. There was significant association between different age group and type of neoplasm. In relation to sex malignant breast neoplasm was more common in female. Conclusion: In conclusion invasive ductal carcinoma was the commonest lesion of breast. In relation to sex malignant breast neoplasm was more common in female. [Journal of Current and Advance Medical Research 2018;5(2):42-44]

Keywords: Malignant neoplasm, Invasive ductal carcinoma, age \& sex

Correspondence: Dr. Nazmun Nahar, Associate Professor \& Head, Department of Pathology, Medical College for Women \& Hospital, Uttara, Dhaka, Bangladesh; Cell no.: +8801914140697; Email: iqbal085nahar082@ gmail.com

Cite this article as: Nahar N, Iqbal M, Rahman KMS, Yusuf MA, Iqbal S, Hossain S. Histopathological Study of Malignant Neoplasm of Breast of Different Age and Sex Groups In a Tertiary Care Hospital. J Curr Adv Med Res 2018;5(2):42-44

Funding: This study has been performed without any funding from outside else.

Conflict of Interest: There was no conflict of interest to any of the authors.

Contributions to authors: Nahar N, Rahman KMS, Iqbal S, Hossain S have contributed in protocol preparation, data collection, data analysis up to the report writing; Nahar N, Iqbal M, Yusuf MA, Iqbal S, Hossain S have written \& revised the manuscript.

Copyright: (02018. Nahar et al. Published by Journal of Current and Advance Medical Research. This article is published under the Creative Commons CC BY-NC License (https://creativecommons.org/licenses/by-nc/4.0/). This license permits use, distribution and reproduction in any medium, provided the original work is properly cited, and is not used for commercial purposes. 


\section{Introduction}

Mammary glands have physical as well as psychological importance in human female ${ }^{1}$. The breast is a modified sweat gland composed of both epithelial and connective tissue elements ${ }^{2}$. Therefore, each element is the source of both benign and malignant disease ${ }^{3}$. Both benign and malignant diseases occur in men and women of all ages ${ }^{4}$. Especially, the large majority of breast cancers are detected during the reproductive and menopausal age ${ }^{5}$. Malignant breast neoplasm is the most common non-skin malignancy in women and is second only to lung cancer as a cause of cancer death ${ }^{6}$. Diagnosis of benign from malignant lesions is important in breast neoplasm ${ }^{7}$. These malignant breast neoplasm comprises several tumor subtypes with distinct etiologies and clinical outcomes ${ }^{8-9}$. The purpose of the present study was to determine the frequency of different types of malignant neoplasm of breast in different age and sex.

\section{Methodology}

This cross-sectional study was carried out at the Department of Pathology, Chittagong Medical College, Bangladesh one year period from May 2005 to June 2006 for a period of one year. Patients presented with breast lump of different age and sex were subjected to this study. The specimens were received from indoor patient Department of Surgery, Chittagong Medical College, Bangladesh. The patient presents with definite palpable lump, irrespective of age and sex were included in this study. Specimens of paraffin embedded tissue were sectioned and stained with hematoxylin and eosin. All tissue were examined histopathologically. All data were statistically evaluated in SPSS version 17.0.

\section{Result}

This present histological study was done in 48 specimen of breast lump. Among these benign and malignant were 21 and 27, respectively. In this paper, we discussed only 27 malignant neoplasm. In table 1 showed highest incidence $96.3 \%$ of malignant neoplasm of breast was found in female. Whereas $3.7 \%$ found in male.

In table 2 showed that a total of 48 patients with breast lump underwent histopathological study. Maximum number of patients $11(22.9 \%)$ were in the age group $31-40$ years $\left(4^{\text {th }}\right.$ decade $)$ and $41-50\left(5^{\text {th }}\right.$ decade) years, respectively. Frequency was lowest $03(6.2 \%)$ in the age group $>60$ years.

\section{Table 1: Distribution of Malignant Breast Lesion According to Sex}

\begin{tabular}{|l|c|c|}
\hline Gender & Frequency & Percent \\
\hline Female & 26 & 96.3 \\
\hline Male & 1 & 3.7 \\
\hline Total & $\mathbf{2 7}$ & $\mathbf{1 0 0 . 0}$ \\
\hline
\end{tabular}

The highest incidence of malignant tumour $9(33.3 \%)$ were found in the age group of $41-50$ years $\left(5^{\text {th }}\right.$ decade). Next incidence of 6(22.2\%) were found in the age group of 31-40 years ( $4^{\text {th }}$ decade). In addition to there is significant association between different age groups and types of breast neoplasm ( $p$ value $0.001)$.

Table 2: Association between Age Group with Benign and Malignant Neoplasm of 48 Breast Lump

\begin{tabular}{|l|l|l|l|}
$\begin{array}{l}\text { Age } \\
\text { Group } \\
\text { Years) }\end{array}$ & $\begin{array}{l}\text { Type of Neoplasm } \\
\text { Malignant }\end{array}$ & \multicolumn{1}{|c}{ Total } \\
\hline 11 to 20 & $9(42.9)$ & $0(0.0)$ & $9(18.8)$ \\
\hline 21 to 30 & $5(23.8)$ & $5(18.5)$ & $10(20.8)$ \\
\hline 31 to 40 & $5(23.8)$ & $6(22.2)$ & $11(22.9)$ \\
\hline 41 to 50 & $2(9.5)$ & $9(33.3)$ & $11(22.9)$ \\
\hline 51 to 60 & $0(0.0)$ & $4(14.8)$ & $4(8.3)$ \\
\hline 61 to 70 & $0(0.0)$ & $3(11.1)$ & $3(6.2)$ \\
\hline Total & $21(100.0)$ & $27(100.0)$ & $48(100.0)$ \\
\hline
\end{tabular}

$P$ value $=0.0001$; Figure within parenthesis indicates percent.

Histopathological categories of malignant cases in different age groups are shown in table-3. In present study among malignant neoplasm, highest incidence $22(81.5 \%)$ of Invasive ductal carcinoma (IDC) and it was commonly found $9(33.4 \%)$ in between $41-50$ years. On the contrary, no frequency of malignant neoplasm is found in the age group 11 to 20 (Table $3)$.

\section{Discussion}

The frequencies of malignant disease was high $12(66.6 \%)$ cases in the age groups $41-50$ years $\left(5^{\text {th }}\right.$ decades) followed by $09(42.8 \%)$ cases in the age groups 31-40 years ( $4^{\text {th }}$ decades).The frequency of malignant diseases was low $0(0 \%)$ in the age group 11 to 20 years. Moormeier ${ }^{10}$ (1996) studied on 10,000 cases of breast lumps. The frequency of malignant diseases was high $(80 \%)$ in the $4^{\text {th }}$ and $5^{\text {th }}$ 
decades. This result was similar to that of present study.

Table 3: Histopathological Categories of Malignant Cases in Different Age Groups (n=27)

\begin{tabular}{|l|c|c|c|c|c|c|c|}
\hline Types & \multicolumn{7}{|c|}{ Age Group (Years) } \\
& $\mathbf{1 1}$ to 20 & $\mathbf{2 1}$ to 30 & $\mathbf{3 1}$ to 40 & $\mathbf{4 1}$ to 50 & $\mathbf{5 1}$ to 60 & $\mathbf{6 1}$ to 70 & \\
\hline IDC & $0(0.0 \%)$ & $3(11.1 \%)$ & $4(14.8 \%)$ & $9(33.4 \%)$ & $3(11.1 \%)$ & $3(11.1 \%)$ & $22(81.5 \%)$ \\
\hline ILC & $0(0.0 \%)$ & $1(3.7 \%)$ & $0(0.0 \%)$ & $0(0.0 \%)$ & $0(0.0 \%)$ & $0(0.0 \%)$ & $1(3.7 \%)$ \\
\hline IMC & $0(0.0 \%)$ & $0(0.0 \%)$ & $1(3.7 \%)$ & $0(0.0 \%)$ & $0(0.0 \%)$ & $0(0.0 \%)$ & $1(3.7 \%)$ \\
\hline DCC & $0(0.0 \%)$ & $1(3.7 \%)$ & $0(0.0 \%)$ & $0(0.0 \%)$ & $0(0.0 \%)$ & $0(0.0 \%)$ & $1(3.7 \%)$ \\
\hline MPh & $0(0.0 \%)$ & $0(0.0 \%)$ & $0(0.0 \%)$ & $0(0.0 \%)$ & $1(3.7 \%)$ & $0(0.0 \%)$ & $1(3.7 \%)$ \\
\hline FS & $0(0.0 \%)$ & $0(0.0 \%)$ & $1(3.7 \%)$ & $0(0.0 \%)$ & $0(0.0 \%)$ & $0(0.0 \%)$ & $1(3.7 \%)$ \\
\hline Total & $\mathbf{0 ( 0 . 0 \% )}$ & $\mathbf{5 ( 1 8 . 5 \% )}$ & $\mathbf{6 ( 2 2 . 2 \% )}$ & $\mathbf{9 ( 3 3 . 3 \% )}$ & $\mathbf{4 ( 1 4 . 8 \% )}$ & $\mathbf{3 ( 1 1 . 1 \% )}$ & $\mathbf{2 7}(\mathbf{1 0 0 \% )}$ \\
\hline
\end{tabular}

Invasive ductal carcinoma=IDC; Invasive Lobular Carcinoma=ILC; Invasive Medullary Carcinoma=IMC; Duct Cell

Carcinoma=DCC in situ; Malignant Phylloides=MPh; Fibro Sarcoma=FS

In malignant neoplasm, highest incidence $81.5 \%$ of invasive ductal carcinoma and it was commonly found $33.4 \%$ in between $41-50$ years. Anderson et a ${ }^{11}$ showed on 270,124 cases of breast lump. Among malignant tumour, duct cell carcinoma was high $68.5 \%$ in 50 years. This result was also similar to the present study.

In our study, the total number of female patients with malignant neoplasm were 26(96.3\%). The incidence of male breast malignancy was 1(3.7\%). The findings of a similar study done by Mudholkar et $\mathrm{al}^{2}$, which showed malignant breast neoplasm in female $97.6 \%$ and male $2.4 \%$.

\section{Conclusion}

The findings of this study showed that the frequency of malignant breast neoplasm is increasing with age. Among these invasive ductal carcinoma is the commonest and mostly affected female.

\section{References}

1. Aziz M, Ahmad N, Zahid J. Comparison of FNAC and open biopsy in palpable breast lumps. Journal of the College of Physicians and Surgeons--Pakistan: JCPSP. 2004;14(11):654-6

2. Mudholkar VG, Mashal SN, Kawade SB. Histopathological Study of Neoplastic Lesions of Breast. Indian Medical Gazette.2012;335-364
3. Lester, S.C. The breast. In: Kumar V, Abbas AK, Fausto $\mathrm{N}$, Aster JC. Robbins and Cotran pathologic basis of disease. $9^{\text {th }}$ edition. London: W.B. Saunders Company. 2015;1043

4. Khan S, Kapoor AK, Khan IU, Shrestha GB, Singh P. Prospective study of pattern of breast diseases at Nepalgunj Medical College (NGMC), Nepal. Kathmandu University Medical Journal, 2003;1(2):95-100

5. Rosai J. Rosai and Ackerman's surgical pathology. vol II. 9th. Edinburgh: Mosby, 2004;1763-1876

6. Lester SC. The breast. In: V Kumar, AK Abbas, N Fausto. Eds. Robbins and Cortan pathologic basis of disease. $7^{\text {th }}$ edition. London: W.B. Saunders Company, 2004;1043

7. Kahn ZM. The frequency of various causes of breast lumps in females presenting to surgical OPD in a tertiary care hospital. Annals of Pakistan Institute of Medical Sciences 2013;9(1):26-9

8. Millikan RC, Newman B, Tse CK, Moorman PG, Conway K, Smith LV, Labbok MH, Geradts J, Bensen JT, Jackson S, Nyante S. Epidemiology of basal-like breast cancer. Breast cancer research and treatment. 2008;109(1):123-39

9. O'Brien KM, Cole SR, Tse CK, Perou CM, Carey LA, Foulkes WD, Dressler LG, Geradts J, Millikan RC. Intrinsic breast tumor subtypes, race, and long-term survival in the Carolina Breast Cancer Study. Clinical Cancer Research. 2010;16(24):6100-10

10. Moormeier J. Breast cancer in black women. Annals Internal Medicine 1996;124(10): 897-905

11. Anderson WF, Pfeiffer RM, Dores GM, Sherman ME. Comparison of age distribution patterns for different histopathologic types of breast carcinoma. Cancer Epidemiology and Prevention Biomarkers. 2006;15(10):1899-905 